About authors:

Raffaele Alessandro, MD, Pediatric Surgery Unit; tel.: +393396442065; e-mail: a.raffaele@smatteo.pv.it

Romano Piero, MD, Pediatric Surgery Unit; e-mail: p.romano@smatteo.pv.it

Guazzotti Marinella, MD, Pediatric Surgery Unit; e-mail: m.guazzotti@smatteo.pv.it

Vatta Fabrizio, MD, Pediatric Surgery Unit; e-mail: fabriziovatta@gmail.com

Cavaiuolo Silvia, MD, Pediatric Surgery Unit; e-mail: s.cavaiuolo@smatteo.pv.it

Brunero Marco, MD, Pediatric Surgery Unit; e-mail: m.brunero@smatteo.pv.it

Avolio Luigi, MD, Pediatric Surgery Unit; e-mail: I.avolio@smatteo.pv.it

Parigi Gian Battista, MD, Professor, University of Pavia, and Pediatric Surgery Unit, IRCCS Policlinico San Matteo; e-mail: gbparigi@unipv.it

(c) Group of authors, 2018

UDC 616.756.22-052.2/.3

DOI - https://doi.org/10.14300/mnnc.2018.13081

ISSN - 2073-8137

\title{
TREATMENT OF UMBILICAL GRANULOMA IN NEONATES
}

\author{
Bolotov lu. N., Minaev S. V., Kachanov A. V., Doronin F. V., Sukhanova A. S., Afanasova A. I.
}

Stavropol State Medical University, Russian Federation

\section{АЕЧЕНИЕ ФУНГУСА ПУПКА У ГРУАНЫХ АЕТЕЙ}

\section{Ю. Н. Болотов, С. В. Минаев, А. В. Качанов, Ф. В. Аоронин,}

А. С. Суханова, А. И. Афранасова

\section{Ставропольский госуАарственный меАицинский университет, Российская ФеАерация}

Umbilical granuloma is the most common umbilical abnormality in young infants and neonates. This prospective study was conducted on 21 infants (28-63 days old) with an umbilical granuloma. The treatment, performed in the patient's home, comprised application of common (edible) salt on the lesion twice a day for 5 days. Results were good in all cases. Thus, application of common salt for treating umbilical granulomas is simple and safe.

Keywords: umbilical granuloma, infants, treatment

Фунгус - одно из часто встречающихся заболеваний пупка у новорожденных и грудных детей. Было проведено проспективное исследование 21 ребенка в возрасте 28-63 дней, лечившихся амбулаторно. Лечение проводилось родителями дома путем аппликаций кристаллов столовой соли на фунгус под лейкопластырной наклейкой на 20 минут дважды в день, на протяжении 5 дней. У всех пациентов был получен хороший результат. Таким образом, использование предлагаемой методики показало ее эффективность и безопасность в лечении фунгуса пупка у грудных детей.

Ключевые слова: фунгус пупка, дети, лечение

For citation: Bolotov lu. N., Minaev S. V., Kachanov A. V., Doronin F. V., Sukhanova A. S., Afanasova A. I. TREATMENT OF UMBILICAL GRANULOMA IN NEONATES. Medical News of North Caucasus. 2018;13(3):477-479.

DOI - https://doi.org/10.14300/mnnc.2018.13081

Для цитирования: Болотов Ю. Н., Минаев С. В., Качанов А. В., Доронин Ф. В., Суханова А. С., Афанасова А. И. ЛЕЧЕНИЕ ФУНГУСА ПУПКА У ГРУДНЫХ ДЕТЕЙ. Медицинский вестник Северного Кавказа. 2018;13(3):477-479. DOI - https://doi.org/10.14300/mnnc.2018.13081

U mbilical granuloma is the most common umbilical pathology in newborns and young children [1, 2], developing in about 1 in 500 births [3]. The umbilical granuloma is overgrown tissue that develops during the healing process of the navel, usually in response to a mild infection. It appears as a soft, pink or red lump and is often wet, oozing a small amount of clear or yellow fluid. Umbilical cord granulomas do not contain nerves and thus have no sensation [4]. The umbilical cord is usually separated within $7-10$ days after delivery [5]. Normally, the granulation tissue of an absorbable umbilical stump of a newborn disappears by the second or third week of life. If present after this time, the persistent granuloma requires attention. Methods for treating umbilical granulomas include chemical cauterization with silver nitrate or copper sulfate, cryo-cauterization, electrical cautery, a double-ligature technique, and surgical excision. In addition, in 1972, Schmitt described the drying effect of table salt on umbilical granulomas [6].

Our study aimed to evaluate the therapeutic effect of edible salt on umbilical granulomas in neonates. 
Material and Methods. This prospective study was conducted at the Pediatric Surgery Outpatient Department of our hospital. Data were collected between August 2016 and May 2018. Altogether, 21 infants with an umbilical granuloma (12 (57.1\%) boys, $9(42.9 \%)$ girls; mean age $38.6 \pm 7.5$ days) were the target group. The parents had given informed written consent. The parents were asked to follow a prescribed regimen, which included (1) cleaning the granuloma and surrounding area with a cotton ball soaked in warm water; (2) applying a small pinch of common salt over the umbilical granuloma; (3) cover the area with adhesive tape for $20 \mathrm{~min}$; and (4) remove the tape and again clean the lesion using a cotton ball soaked in warm water. The entire procedure was repeated twice a day for 5 days. The surgeon evaluated the patient's progress twice: before and after treatment. Parents kept a treatment diary with daily photographs to visually map the treatment dynamics.

The healing criteria for these fungus-infected lesions were as follows: good - complete healing of the lesion by the end of treatment; satisfactory - incomplete wound healing with partial epithelialization ( $<50 \%$ ); unsatisfactory - absence of wound healing by the end of treatment.

Statistica 10.0 (StatSoft, Tulsa, OK, USA) was used for statistical data analyses, which included standard descriptive and analytical statistical methods.

Results and Discussion. All 21 infants included in the study were evaluated on the sixth day after the start of treatment. Patients were assessed for the state of the granuloma (possibly infected with a fungus) and skin in the area of the umbilical ring. All infants completed the study with good follow-up results. No adverse effects of common salt were observed.

Concomitant diseases (i.e., perinatal encephalopathy, lactase deficiency) that were present in some of the infants had no effect on the formation of hypertrophic scars. There were also no differences in the propensity to form hypertrophic scars according to age or sex.

Good compliance-salt administration twice daily for 20 min per application for 5 days-was seen for 20 of the $21(95.2 \%)$ patients. The other infant $(4.8 \%)$ had satisfactory compliance (the parents sometimes forgot to perform the second application).

A representative clinical example was patient $B$, a 6-weekold female infant who was referred to us with pink tissue protruding from the umbilicus. She was born at term with a birth weight of $3600 \mathrm{~g}$. The pregnancy had been unremarkable, with a normal prenatal ultrasonography scan. There was no family history of congenital anomalies. Her parents had noted the unusual nature of the infant's umbilicus 1 week prior to her first visit to our department. Its size had doubled from the time it was first noticed. The infant was otherwise well, with no signs of intestinal obstruction. On clinical examination, we noted pink-red, fleshy tissue, about $0.8 \mathrm{~cm}$ diameter, protruding from the umbilicus (Figure). Umbilical granuloma was diagnosed. Treating it with common salt was recommended, which was started on the sixth day after the umbilical granuloma was diagnosed. The outcome was good.

The most common umbilical problem in infants is the umbilical granuloma. Numerous treatments have been tried, including chemical moxibustion with silver nitrate or copper sulfate, cryolite cryolysis, electric moxibustion, a double-ligature technique, and surgical removal. Each treatment has advantages and disadvantages. For example, chemical moxibustion with silver nitrate or copper sulfate may cause a slight burn of the periumbilical area of the skin [7]. Electrocautery and cryocauterization require that clinics be equipped with special devices, increasing the cost of treatment. Skin discoloration has been reported as a complication of these procedures $[3,8]$.
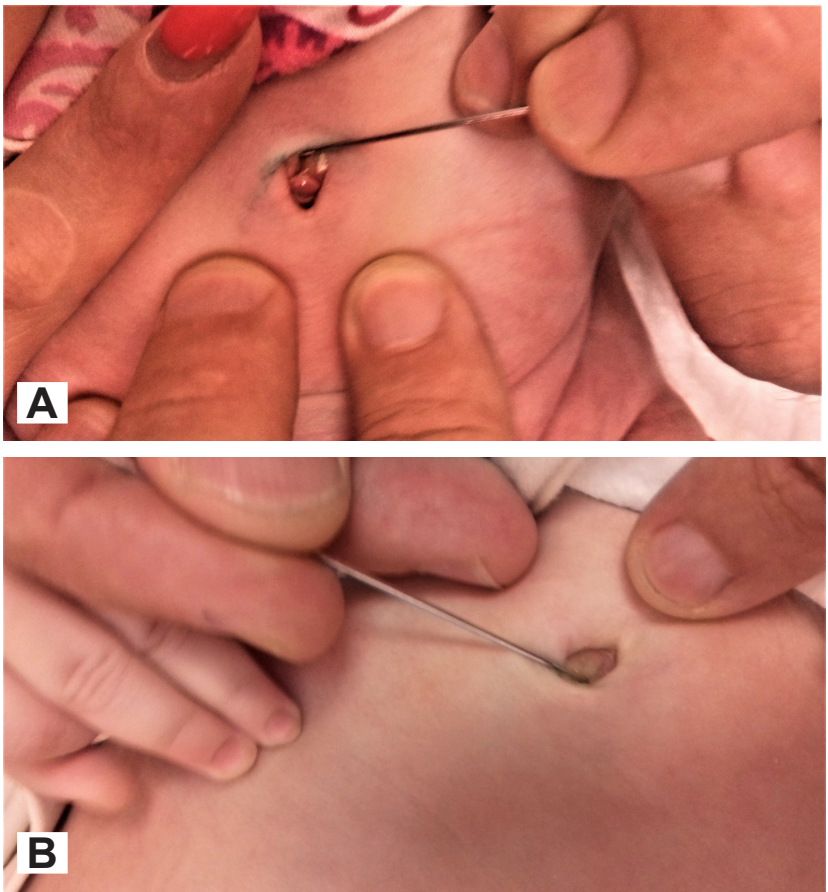

Fig. Infant with an umbilical granuloma possibly due to a fungal infection: A - before treatment; B - after treatment. The treatment result was «good» in that there was total elimination of the fungus and complete epithelialization of the skin defect

The double ligature method is simple to perform and provides good cosmetic and functional results with minor complications. The only contraindications for using this technique are large sessile umbilical cord granulomas with a wide base, small deep lesions, and very loose foci that can bleed during the procedure [9].

Treatment of umbilical granuloma at home with topical clobetasol propionate $(0.05 \%)$ cream is as effective as treatment with topical silver nitrate (99\%) in the clinic [10]. Topical clobetasol propionate, however, has been found to suppress the hypothalamic-pituitary-adrenal axis. Hence, it has been suggested that it be used only in patients over 12 years of age [11]. Finally, surgical removal requires general anesthesia as well as an experienced physician, usually a surgeon, and sterile conditions and equipment [12].

Conclusions. The therapeutic mechanism of salt, when used to treat umbilical cord granulomas, is its influence as a desiccant and its other biological properties. A high concentration of sodium ions in the area draws water from the cells, thereby resulting in drying and necrosis of moist granulation tissue. This effect is not so strong that it damages the surrounding normal keratinized tissue when applied via injection for the entire treatment period. Thus, our study confirmed that application of common salt for treating umbilical granuloma is simple and safe.

\section{Disclosures:}

The authors declare no conflict of interest

Acknowledgment. We thank Nancy Schatken, BS, MT(ASCP), from Edanz Group (www.edanzediting.com/ac), for editing a draft of this manuscript. 


\section{References}

1. Al Saleh A. S. Therapeutic effect of common salt on umbilical granuloma in infants. Int. J. Med. Sci. Public. Health. 2016;5(5):911-914

https://doi.org/10.5455/ijmsph.2016.07012016312

2. Hossain A. Z., Hasan G. Z., Islam K. D. Therapeutic effect of common salt (table/cooking salt) on umbilical granuloma in infants. Bangladesh J. Child Health. 2010;34(3):99102. https://doi.org/10.3329/bjch.v34i3.10360

3. Assi A. N., Kadem M. K., Al Rubaee R. J., Atshan F. G. Management of umbilical granuloma. Thi-Qar Medical Journal (TQMJ). 2010;4(4):82-87.

4. O'Donnell K. A., Glick P. L., Caty M. G. Pediatric umbilical problems. Pediatr. Clin. North. Am. 1998;45(4):791-799. https://doi.org/10.1016/S0031-3955(05)70045-6

5. Wilson C. B., Ochs H. D., Almquist J., Dassel S., Mauseth $R$. [et al.] When is umbilical cord separation delayed? J. Pediatr. 1985;107(2):292-294.

6. Schmitt B. D. Tip of the month: shrinking umbilical granulomas. Consultant. 1972:12:91.

7. Chamberlain J. M., Gorman R. L., Young G. M. Silver nitrate burns following treatment for umbilical granuloma. Pediatr. Emerg. Care. 1992;8(1):29-30.

https://doi.org/10.1097/00006565-199202000-00008
8. Sheth S. S., Malpani A. The management of umbilical granulomas with cryocautery. Am. J. Dis. Child. 1990;144(2):146-147.

9. Lotan G., Klin B., Efrati Y. Double-ligature: treatment for pedunculated umbilical granulomas in children. Am. Fam. Physician. 2002;65(10):2067-2068.

10. Brodsgaard B. Nielsen T, Mølgaard U., Pryds O. Pedersen P. Treating umbilical granuloma with topical clobetasol propionate cream at home is as effective as treating it with topical silver nitrate in the clinic. Acta Paediatr. 2015;104(2):174-177. https://doi.org/10.1111/apa.12824

11. Aydin M., Orman A., Deveci U., Taskin E. Topical clobetasol propionate may not be safe for treating umbilical granuloma in infants. Acta Paediatr. 2015;104(2):e49.

12. Karagüzel G., Aldemir H. Umbilical granuloma: modern understanding of etiopathogenesis, diagnosis, and management. J. Pediatr. Neonatal Care. 2016;4(3):00136. https://doi.org/10.15406/jpnc.2016.04.00136

About authors:

Bolotov Iuriy Nikolaevich, Assistant Professor, Department of Pediatric Surgery; tel.: +79187838354; e-mail: b-y-n@rambler.ru

Minaev Sergey Viktorovich, MD, PhD, Professor, Head of the Department of Pediatric Surgery;

tel.: +79624507653; e-mail: sminaev@yandex.ru

Kachanov Alexander Vasilyevich, MD, Pediatric Surgeon, Laboratory Assistant of the Department of Pediatric Surgery with DPO Course; tel.: +79283174974; e-mail: 89283174974@mail.ru

Doronin Fedor Vladimirovich, MD, Associate Professor, Department of Pediatric Surgery; tel.: +79054914529; e-mail: fedor.doronin@mail.ru Sukhanova Anastasia Sergeevna, student in the Pediatric Faculty; tel.: +79187915423; e-mail: a.s.alibash@gmail.com

Afanasova Alexandra Igorevnovna, student in the General Medicine Faculty; tel.: +79899918099; e-mail: alex.afanasowa@mail.ru

(c) Group of authors, 2018

UDC 617-089616.36:616-005.4:616-008.9-74

DOI - https://doi.org/10.14300/mnnc.2018.13082

ISSN - 2073-8137

\title{
CLINICAL EFFICACY OF A NOVEL DOSED TISSUE DISTRACTION METHOD IN THE TREATMENT OF SOFT TISSUE DEFECTS IN THE LOWER LIMBS
}

Pyatakov S. N. ${ }^{1}$, Porkhanov V. A. ${ }^{2}$, Baryshev A. G. ${ }^{1}$, Pyatakova S. N. ${ }^{3}$, Bardin S. A. ${ }^{1}$, Suzdaltsev I. V. ${ }^{4}$

${ }^{1}$ Kuban State Medical University, Krasnodar, Russian Federation

2 S. V. Ochapovsky Regional Clinical Hospital № 1, Krasnodar, Russian Federation

${ }^{3}$ City Hospital № 4, Sochi, Russian Federation

${ }^{4}$ Stavropol State Medical University, Russian Federation

\section{ИЗУЧЕНИЕ КАИНИЧЕСКОЙ ЭФФЕКТИВНОСТИ МЕТОАА АОЗИРОВАННОЙ ТКАНЕВОЙ АИСТРАКЦИИ ПРИ АЕЧЕНИИ АЕФЕКТОВ МЯГКИХ ТКАНЕЙ РАЗАИЧНОЙ ЭТИОАОГИИ В ОБААСТИ НИЖНИХ КОНЕЧНОСТЕЙ}

\author{
C. Н. Пятаков 1 \\ С. А. Бардин ${ }^{1}$, \\ В. А. Порханов ${ }^{2}$, А. Г. Барышев ${ }^{1}$, С. Н. Пятакова ${ }^{3}$, \\ И. В. СузАальцев 4
}

1 Кубанский госуАарственный МеАицинский Университет, КрасноАар,
Российская ФеАерация

2 Научно-исслеАовательский институт - Краевая кАиническая больница № 1 имени профессора С. В. Очаповского, Краснодар, Российская ФеАерация

3 Горолская больница № 4, Сочи, Российская Фелерация

${ }^{4}$ Ставропольский госуАарственный меАицинский университет, Российская ФеАерация

A comparative assessment of the original method of DTD for skin defects closure in the lower limbs compared with traditional approaches has been made. 345 patients and injuries with skin and soft tissues defects of lower limbs were included in the analysis, out of which standard approaches were applied to the treatment of 164 patients, the original 